\title{
Environment of Viewpoint Geosites: Evidence from the Western Caucasus
}

\author{
Anna V. Mikhailenko ${ }^{1}$ and Dmitry A. Ruban ${ }^{2,3,4, * \mathbb{D}}$ \\ 1 Department of Physical Geography, Ecology, and Nature Protection, Institute of Earth Sciences, \\ Southern Federal University, Zorge Street 40, Rostov-on-Don 344090, Russia; avmihaylenko@sfedu.ru \\ 2 Department of Economics and Management, Business School, Cherepovets State University, \\ Sovetskiy Avenue 10, Cherepovets, Vologda Region 162600, Russia \\ 3 Department of Business in Hospitality Sphere, Higher School of Business, Southern Federal University, \\ 23-ja linija Street 43, Rostov-on-Don 344019, Russia \\ 4 K.G. Razumovsky Moscow State University of Technologies and Management (the First Cossack University), \\ Zemlyanoy val 73, Moscow 109004, Russia \\ * Correspondence: ruban-d@mail.ru
}

Received: 6 May 2019; Accepted: 12 June 2019; Published: 13 June 2019

check for updates

\begin{abstract}
Viewpoint geological and geomorphological heritage sites (geosites and geomorphosites) offer panoramic views over unique geological features and landscapes dominated by significant features. The environmental context is of crucial importance for these sites. Three components of a viewpoint geosite environment are proposed: standpoint environment, transitional environment, and target environment. Each can be evaluated with a set of criteria such as presence of geological and geoheritage elements, presence and type of vegetation cover, anthropogenic intervention, and degree of fragmentation and contrast. Three examples of viewpoint geosites from the Western Caucasus are analyzed. It is shown that all three demonstrate differences between the noted components of viewpoint geosite environment. Moreover, the differences between these geosites result from their environmental differences and less from differences of their displayed geoheritage. Broad applications and further justifications of the environmental evaluation method of viewpoint geosites are recommended.
\end{abstract}

Keywords: anthropogenic influences; geological heritage; mountainous Adygeja; panoramic viewing; vegetation cover

\section{Introduction}

Research in geological heritage (geoheritage) and geotourism has gained measurable importance during the past two decades, and it now boasts a solid theoretical foundation [1-3]. Although this kind of research focuses on unique geological phenomena valued in science, education, and tourism, it has become increasingly linked to environmental studies. For instance, the ecosystem services approach [4-6] has been employed successfully in geoheritage and geodiversity studies [7,8]. Geoheritage sites (geosites) include geosites representing unique geological phenomena $[3,9,10]$ and geomorphosites representing unique landforms [11-16]. Geological and geomorphological phenomena are often indivisible, and, thus, the general term 'geosite' can be used broadly, although the term 'geomorphosite' is appropriate when site value is determined by landform uniqueness. Undoubtedly, the integrity of geosites cannot be realized without attention to their landscape context. Full integration of geoheritage and environmental research is on the agenda, but this ambitious and multidimensional task is yet to be achieved.

Recently, Migoń and Pijet-Migoń [17] conceptualized a peculiar category of geosites, namely viewpoint geosites offering panoramic over-views of major geological structures and domains. These 
geosites (and geomorphosites) may be found along roads, at cliff edges, on mountain summits, at bottoms of deep depressions, on roofs of tall buildings, etc. Their heritage importance is linked not to unique in situ geological features but to physical parameters permitting an enhanced comprehension of geology-dominated landscapes and landforms. Examples of such geosites can be found, particularly, in the Zagros Mountains of Iran, where panoramic views to peculiar geological and geomorphological features are available from Shiraz city [18], and also in the unique volcanic domain of Cameroon [19]. Apparently, viewpoint geosites demonstrate geoheritage-environment relationships so sharply because of three reasons. First, these geosites do not (and cannot) focus only on geology and/or landforms offering panoramic views. Second, the state of the local environment has an influence on parameters of viewpoint geosites permitting better or worse visibility of heritage features (cf. [17]). Third, the value of such sites is linked strongly to their aesthetic properties, and the very act of panoramic viewing refers to some basic judgments of beauty as specified by Kirillova et al. [20]. If so, environmental considerations appear to be very crucial for evaluation of viewpoint geosites.

This brief contribution proposes a tentative approach for the environmental evaluation of viewpoint geosites. It is tested with three examples from the Western Caucasus (southwestern Russia), which boasts both of a rich geoheritage [21] and numerous, easily accessible points for panoramic viewing.

\section{Conceptual Remarks and Methodology}

\subsection{Composition of the Viewpoint Geosite Environment}

The concept of a viewpoint geosite is appealing, but, unfortunately, the only work to explore this idea is by Migon and Pijet-Migon [17]. Those authors proposed a simple scheme for evaluation of such geosites with several criteria, namely physical parameters of views (width, depth, and vertical extension), geodiversity, and presence of manmade features. These criteria refer to visibility, geoheritage itself, and human imprint, respectively. As such, these are linked chiefly to geoheritage and less to the environment. In regard to the especially high importance of the environmental dimension to viewpoint geosites (see above), such geosites deserve a more nuanced environmental evaluation.

A specific feature of viewpoint geosites is their composition. Such geosites include two main components, namely the point where observers stand and the distant object under observation. Their environments may be different. For instance, an observer may stand on a road crossing or the bottom of a densely forested valley, whereas the object of observation is a massive outcrop of folded rocks near the glaciated summit of a nearby mountain. Moreover, it is difficult to believe that an observer would focus on only geoheritage. Many observers may look around enjoying the panoramic view, where nongeological features (landforms, trees, houses, etc.) are easier to understand than geological features. Generally, the viewpoint geosite environment consists of three components: standpoint environment, transitional environment, and target environment (Figure 1).

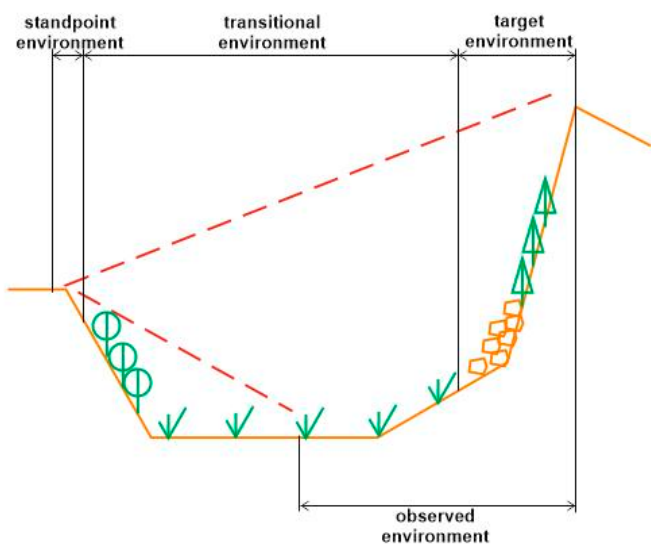

Figure 1. Main components of the viewpoint geosite environment. 
Depending on the physical parameters of a given panoramic view, the transitional environment may dominate the perceived landscape image. Sometimes, the only parts of transitional and target environments are visible, and, thus, it is sensible to distinguish such a component as an observed environment (Figure 1). The distance between standpoint and target may be up to several kilometers. Moreover, there may be substantial differences in elevation. It is sensible to characterize the components of the viewpoint geosite environment separately.

\subsection{Criteria for the Evaluation of Viewpoint Geosite Environment}

Environment can be characterized by various criteria and schemes depending on the analytical needs. In this paper, the following criteria are provisionally employed:

- presence of geological elements;

- presence of geoheritage elements;

- presence of geomorphological elements;

- presence of geomorphological heritage elements;

- presence and type of vegetation cover;

- $\quad$ presence of uncovered soil;

- presence of water (rivers, lakes, and seas);

- $\quad$ presence of snow/ice;

- presence of cultural/historical elements (for instance, historical buildings);

- degree of anthropogenic intervention (stress) (relative number of non-natural elements, including those relevant to geosite infrastructure [17]; judgments of whether manmade elements are positive or negative to the landscape depend on individual preferences (cf. [20]), and, thus, the overall anthropogenic intervention should be taken into account);

- degree of landscape richness (number of different types of elements mentioned above);

- degree of landscape degradation (because of natural processes like rockfalls or anthropogenic processes like massive construction, land abandonment, etc.);

- degree of landscape cleanness (absence of garbage left by residents and/or tourists);

- degree of landscape openness;

- degree of landscape fragmentation (mosaic) [22];

- degree of landscape contrast (visual difference of landscape-for instance, by color or by height of landscape elements); and

- degree of visible component details belonging to landscape elements (this depends on the both distance to observable environment and size of elements).

Each principal component of a viewpoint geosite environment can be evaluated with these criteria on a semiquantitative basis (i.e., on a scale of $0-4$, where 0 is the minimal value (total absence) and 4 is the maximal value (total dominance, significant abundance)). The criteria that are relevant to the presence of certain landscape elements can be evaluated on the basis of their relative abundances (e.g., $10 \%$ of ice gives a score of 1 , and $90 \%$ of ice gives a score of 4 ). The criteria that are relevant to degree of landscape parameters can be evaluated on the basis of intensity of these parameters (for instance, monotonous grass cover gives a landscape fragmentation score of 0 , and "spotted" occurrence of rocks, snow, grass, and uncovered soil gives a score of 4). The scoring is not relative, and it refers to the real appearance of each pattern and is fixed according to some objective observations. However, all criteria strongly depend on a given situation, and, thus, it would be difficult (if not impossible) to give definite rules for scoring. Such rules differ evidently between territories. Although the judgments are subjective, the degree of subjectivity is unimportant to the present study, which is aimed at showing the very necessity of considering viewpoint geosite environments (the criteria themselves are more important than scoring in our case, and scoring is given only as an example). It should be stressed that this analysis does not (and cannot) aim at answering whether the given environment is 'good' or 'bad' 
because of two reasons. First, many environment elements may be positive or negative depending on a given situation and visitor preferences (for instance, vegetation makes the environment look more natural, but it masks important geological features). Second, visitors may judge differently about natural attributes depending on their individual ideas of beauty [20]. In contrast, two other things are important. First, a general description of the environmental state is necessary for further generalization of the knowledge of what typical environments of viewpoint geosites in different regions of the world are. Second, a similarity between the principal components of a viewpoint geosite environment is a factor of its complexity - the lower the similarity, the higher the complexity of the entire environment.

\section{Case Examples}

\subsection{Study Area}

The Western Caucasus, which is located north from the Black Sea (Figure 2), is a western part of the Greater Caucasus Mountains (geologically, this is a fold-thrust belt [23-25]). It hosts a geodiversity hotspot for the mountainous region of Adygeja, where unique paleontological, sedimentary, paleogeographical, geomorphological, and other features are abundantly exposed [21]. Chiefly, these features are linked to Mesozoic geology (examples are the Late Jurassic carbonate platform rimmed by reefs, the mid-Cretaceous glauconitic sandstones with gigantic ammonite shells, etc.). The environments of the geodiversity hotspot are diverse and include dense forests, riverside meadows, alpine meadows, snowfields, and anthropogenically modified agrarian and urban landscapes.

The dominance of such specific landforms as cuesta-type mountain ranges with tall cliffs and large, cirque-like depressions hosting isolated mountains determines the existence of numerous places for panoramic viewing of geoheritage features (i.e., viewpoint geosites). For instance, Gnezdilova et al. [26] note a locality at the top of the Stonesea Range, from which two mountains are visible-one mountain represents Late Triassic reefs and the other represents Late Jurassic reefs. For the purposes of the present study, three viewpoint geosites are considered, namely the Mishoko Cliff, the Soldatskij Pass, and the Nagai-Koshki Mountain (Figure 2).

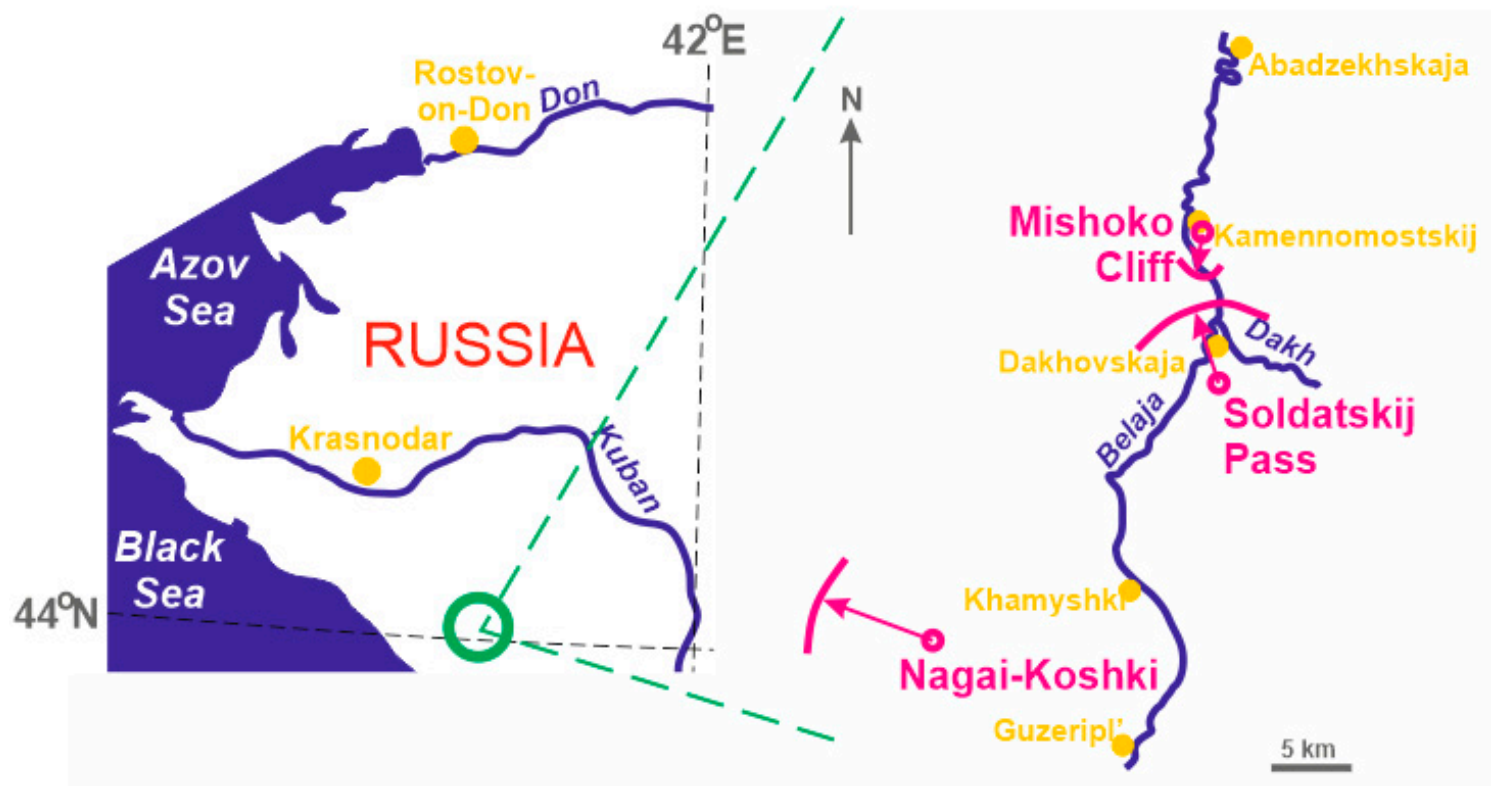

Figure 2. Location of the studied viewpoint geosites (arrows indicate directions of views in Figure 3); in each case, standpoint environment corresponds to circles, transition environment corresponds to arrows, and target environment corresponds to bold, violet lines. 

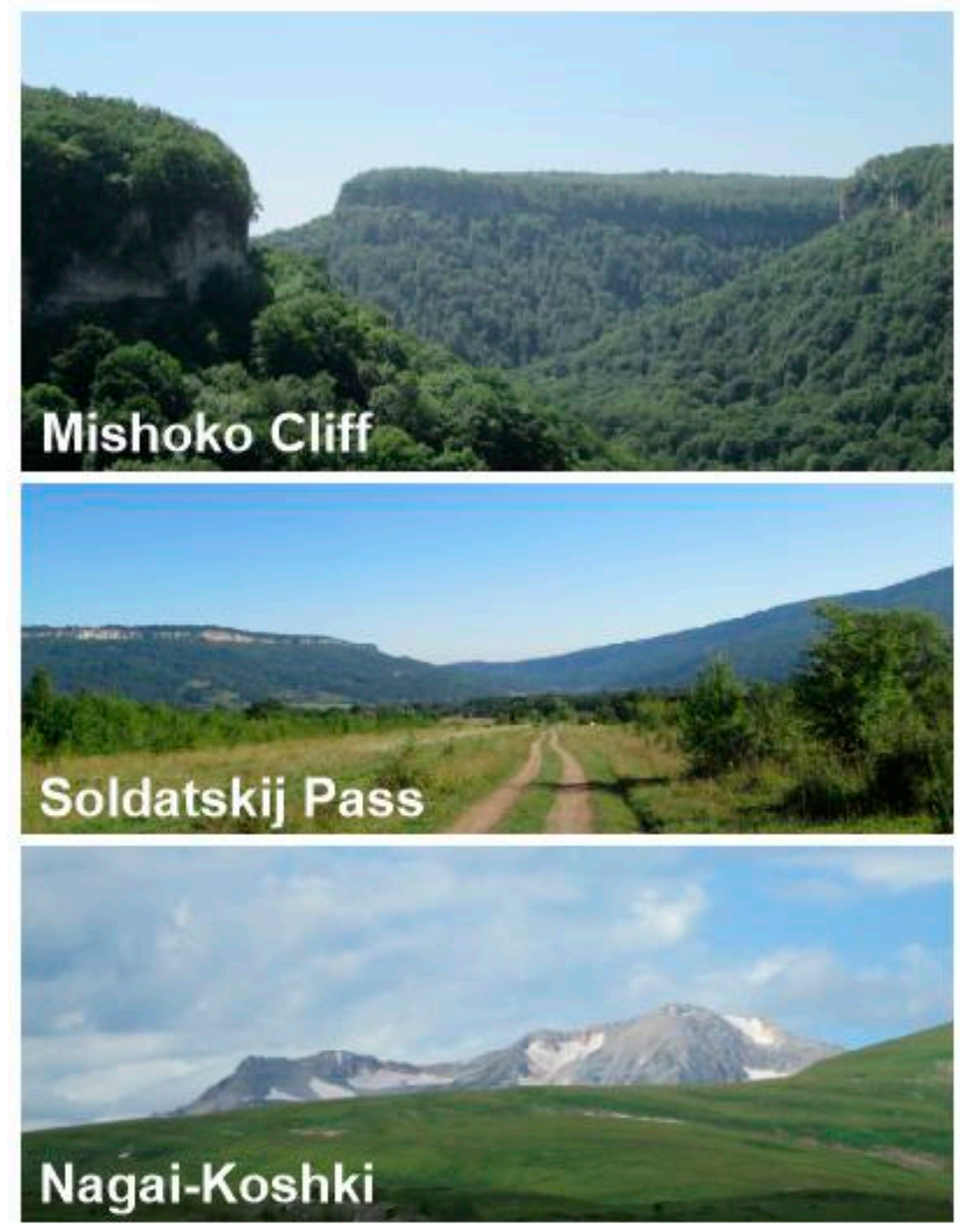

Figure 3. Panoramic views from the studied viewpoint geosites/geomorphosites.

\subsection{Mishoko Cliff Viewpoint Geosite}

This viewpoint geosite is located on the southern periphery of the town of Kamennomostskij, where a $\sim 270^{\circ}$ panoramic view is opened from the cliff edge (Figure 2). The main object of observation is the deep Khadzhokh Canyon cut into hard rocks by the Belaja River, which includes some 'branches' formed by the tributaries of the noted river (Figure 3). This canyon is considered a global geoheritage because of its characteristic shape, important fossil localities, waterfalls, and some other unique geological features [21]. As such, this geosite is also a geomorphosite. This geosite offers a view of the massive Late Jurassic limestones that crop out as a yellowish-white 'ribbon' just below the top of the canyon walls (Figure 3).

Evaluation results of this viewpoint geosite are summarized in Table 1. They permit four general inferences. First, geomorphological elements and the relevant heritage dominate the site. Second, differences between environment components are moderate to low. Third, the entire environment of the site appears to be rather homogenous (chiefly, because of canyon dominance and dense vegetation cover). Fourth, the standpoint environment is in danger because of anthropogenic intervention and garbage storage (from uncontrolled tourist activities). 
Table 1. Environment of the Mishoko Cliff geosite/geomorphosite.

\begin{tabular}{cccc}
\hline Criteria & \multicolumn{2}{c}{ Environment Components } \\
\cline { 2 - 4 } & Standpoint & Transitional & Target \\
\hline presence of geological elements & 3 & 0 & 2 \\
presence of geoheritage elements & 2 & 0 & 2 \\
presence of geomorphological elements & 4 & 4 & 4 \\
presence of geomorphological heritage elements & 4 & 4 & 4 \\
presence and type of vegetation cover & 2 & 4 & 4 \\
presence of uncovered soil & (grass) & (trees) & (trees) \\
presence of water & 1 & 0 & 0 \\
presence of snow/ice & 0 & 0 & 0 \\
presence of cultural/historical elements & 0 & 0 & 0 \\
degree of anthropogenic intervention & 0 & 0 & 0 \\
degree of landscape richness & 2 & 0 & 0 \\
degree of landscape degradation & 1 & 1 & 1 \\
degree of landscape cleanness & 3 & 0 & 0 \\
degree of landscape openness & 2 & 4 & 4 \\
degree of landscape fragmentation & 3 & 2 & 1 \\
degree of landscape contrast & 1 & 1 & 1 \\
degree of visible detailing of landscape elements & 1 & 1 & 1 \\
\hline
\end{tabular}

\subsection{Soldatskij Pass Viewpoint Geosite}

This viewpoint geosite is located on the southern periphery of Dakhovskaja village, where a $\sim 180^{\circ}$ panoramic view is opened from the northern gentle slope of Gud Mountain where the road crosses a local high at its toe (Figure 2). The main object of observation is the Una-Koz Range, which is a typical cuesta-type mountain range with a tall cliff exposed to the south; the range is cut into two parts by the valley of the Belaja River (this is the entrance to the Khadzhokh Canyon) (Figure 3). The Una-Koz Range can be assigned as representing a local geoheritage because it exhibits a typical cuesta landform, and the Late Jurassic highly fossiliferous limestones (a very typical example of the ancient carbonate platform) crop out there. This geosite is also a geomorphosite.

Evaluation results this viewpoint geosite are given in Table 2. These focus on four general inferences. First, geomorphological and less geological elements occur in only the target environment. Second, differences between environment components are moderate. Third, a certain heterogeneity of the entire environment of the site is evident (chiefly, because of the absence of geological and geomorphological features but significant anthropogenic perturbation of the standpoint). Fourth, the standpoint is not in an ideal state because of substantial anthropogenic intervention and land degradation on the village periphery.

Table 2. Environment of the Soldatskij Pass geosite.

\begin{tabular}{cccc}
\hline \multirow{2}{*}{ Criteria } & \multicolumn{2}{c}{ Environment Components } \\
\cline { 2 - 4 } & Standpoint & Transitional & Target \\
\hline presence of geological elements & 0 & 0 & 2 \\
presence of geoheritage elements & 0 & 0 & 2 \\
presence of geomorphological elements & 0 & 0 & 4 \\
presence of geomorphological heritage elements & 0 & 0 & 4 \\
presence and type of vegetation cover & 2 & 3 & 4 \\
presence of uncovered soil & (grass and bushes) & (grass and trees) & 0 \\
presence of water & 1 & 0 & 0 \\
presence of snow/ice & 0 & 0 & 0 \\
presence of cultural/historical elements & 0 & 0 & 0 \\
degree of anthropogenic intervention & 3 & 0 & 0 \\
\hline
\end{tabular}


Table 2. Cont.

\begin{tabular}{cccc}
\hline Criteria & \multicolumn{2}{c}{ Environment Components } \\
\cline { 2 - 4 } & Standpoint & Transitional & Target \\
\hline degree of landscape richness & 1 & 1 & 1 \\
degree of landscape degradation & 3 & 1 & 0 \\
degree of landscape cleanness & 3 & 4 & 4 \\
degree of landscape openness & 3 & 2 & 1 \\
degree of landscape fragmentation & 2 & 2 & 1 \\
degree of landscape contrast & 1 & 2 & 1 \\
\hline
\end{tabular}

\subsection{Nagai-Koshki Viewpoint Geosite}

This viewpoint geosite is located on the southeastern periphery of the Lagonaki Highland, where a $\sim 270^{\circ}$ panoramic view is opened from the northern slope of the Nagai-Koshki Mountain, which is essentially a local high of the Stonesea Range (a very typical cuesta-type mountain range) (Figure 2). The main objects of observation are the Oshten Mountain — the second highest point of the Western Caucasus and the reefal massif of the Late Jurassic tropical sea (Figure 3), the lengthy cuesta-type mountain range with exposures of the Late Jurassic limestones, and the landscape dominated by karst sinkholes. The entire Lagonaki Highland and, particularly, its observed part constitute a world-class geoheritage site, the uniqueness of which is determined, primarily, by palaeogeographical (tropical carbonate facies) and geomorphological (classical karst) features [21,27]. The abundance of unique landforms makes this geosite a geomorphosite.

Evaluation results of this viewpoint geosite are summarized in Table 3. These permit four general inferences to be made. First, geomorphological elements and the relevant heritage dominate the site. Second, differences between environment components are moderate. Third, the entire environment appears to be generally homogenous, although the presence of streams in the transitional environment and snow in the target environment induce some heterogeneity (this is reflected by the different degrees of landscape contrast). Fourth, the danger of anthropogenic perturbation of the landscape is minimal, although it may increase in the near future because of the expanding tourism infrastructure at the standpoint and active trail-making by crowds of tourists in the transitional environment.

Table 3. Environment of the Nagai-Koshki geosite.

\begin{tabular}{cccc}
\hline Criteria & \multicolumn{2}{c}{ Environment Components } \\
\cline { 2 - 4 } & Standpoint & Transitional & Target \\
\hline presence of geological elements & 1 & 1 & 2 \\
presence of geoheritage elements & 1 & 1 & 2 \\
presence of geomorphological elements & 4 & 4 & 4 \\
presence of geomorphological heritage elements & 4 & 4 & 4 \\
presence and type of vegetation cover & 4 & 4 & 4 \\
presence of uncovered soil & (grass and trees) & (grass and trees) & 1 \\
presence of water & 1 & 1 & 0 \\
presence of snow/ice & 0 & 1 & 0 \\
presence of cultural/historical elements & 0 & 0 & 0 \\
degree of anthropogenic intervention & 0 & 0 & 2 \\
degree of landscape richness & 1 & 2 & 0 \\
degree of landscape degradation & 1 & 1 & 4 \\
degree of landscape cleanness & 1 & 4 & 3 \\
degree of landscape openness & 2 & 4 & 1 \\
degree of landscape fragmentation & 4 & 2 & 3 \\
degree of landscape contrast & 2 & 2 & 3 \\
\hline
\end{tabular}




\section{Discussion and Conclusions}

Analysis of the three examples of viewpoint geosites from the Western Caucasus highlights two general inferences. First, the necessity of distinction between the standpoint, transitional, and target environments (Figure 1) is stressed by their differences established in all three cases (Tables 1-3). Second, despite significant similarity of their geoheritage value (Upper Jurassic limestones and the cuesta-type mountain ranges), the viewpoint geosites differ substantially among their respective environments. If the environmental context means so much for perception of panoramic views by visitors (see above and [17]), it is in this context that makes viewpoint geosites of the study area truly diverse and, thus, contributes to geodiversity perception.

The present study illustrates the proposed scoring-based approach to the environmental evaluation of viewpoint geosites. This approach seems to be quite easy to use. It is based on field observations, but analysis of panoramic photos also may be informative. In both cases, it is necessary to identify elements and to describe the state of standpoint, transitional, and target environments as well as to undertake their close field investigation. Environmental evaluation of viewpoint geosites requires examination of not only observation points but also the entire area embraced by panoramic views. It is a question for further discussion whether or not viewpoint geosites themselves should be restricted to observation points or should be understood as big geosites, including the entire area observable from them. The limitations of the proposed approach are two-fold. On the one hand, these are linked to a set of chosen criteria. In fact, some other criteria can be involved, such as criteria relevant to scenic beauty or physical parameters of environmental elements, and some existing criteria can be split into several separate criteria (this is the case of vegetation, which can appear in very different forms like at the Soldatskij Pass geosite-Table 2). On the other hand, scoring for each of these criteria is highly subjective, even if the scores aim to reflect the true proportions of elements or pattern manifestation. Only further research and broad testing of the proposed criteria may justify the utility of this methodology. However, the purposes of our provisional analyses are to demonstrate the importance of non-geoheritage environment evaluation of viewpoint geosites, the necessity of three environmental components as subdivisions, and the possibilities of evaluation on the basis of multiple criteria. For these purposes, the outlined limitations are not crucial.

The present contribution has two practical implications. First, Migoń and Pijet-Migoń [17] are noteworthy for their complexity of geoheritage comprehension via panoramic viewing. Thus, it is important to consider the environmental context of viewpoint geosites for their efficient planning, designing, and maintenance for geotourism purposes. Second, environmental evaluation of the three viewpoint geosites in the Western Caucasus sheds light on different forms of anthropogenic influence, ranging from occasional garbage storage by tourists to land degradation because of excessive agricultural practice and land abandonment. This means that human-related environmental perturbations are to be considered with attention to the smallest of details. Importantly, the degree of anthropogenic intervention is often high in standpoint environments (Tables 1-3). Partly, this is so because the evidence of such an intervention in two other environments is difficult to see from a long distance. However, it should be noted that viewpoint geosites are often located in well-accessible places prone to anthropogenic intervention, whereas the observed environment with geological exposures tends to be less accessible. In any case, the noted tendency is not a rule, and, for instance, road construction on a slope of the observed unique landform provides an example of anthropogenic intervention in the target environment.

Two principal conclusions can be made on the basis of this study. First, environmental context is a crucial factor for viewpoint geosites and geomorphosites, and it requires serious evaluation using multiple criteria. Second, three case examples from the Western Caucasus demonstrate differences between the standpoint, transitional, and target environments of viewpoint geosites. Generally, this work stresses the importance of the environmental dimension of viewpoint geosites that is not supplementary to their geoheritage value. Undoubtedly, future progress in the modern geoheritage and geotourism studies should coincide with paying greater attention to this specific, important sort of 
geosites. Such future development will contribute to a better integration of research on the relationship between geoheritage and environment.

Author Contributions: Conceptualization, D.A.R.; field works, A.V.M. and D.A.R.; methodology, D.A.R.; investigation, A.V.M. and D.A.R.; writing, D.A.R.

Funding: This research was partly supported by the RF President grant MK6548.2018.5, agreement 075-02-2018-136 (contribution of A.V.M.). D.A.R.'s contribution received no external funding.

Acknowledgments: The authors gratefully thank the journal editorial team and the three anonymous reviewers for their helpful recommendations and support. Linguistic polishing by M.E. Johnson (USA) is highly appreciated.

Dedication: This paper is dedicated to the memory of Andrey S. Orlinskiy and Vladimir I. Pugachev who assisted the authors in their field works for many years.

Conflicts of Interest: The authors declare no conflict of interest.

\section{References}

1. Gray, M. Geodiversity. Valuing and Conserving Abiotic Nature; Wiley-Blackwell: Chichester, UK, 2013; pp. 1-495.

2. Prosser, C.; Murphy, M.; Larwood, J. Geological Conservation: A Guide to Good Practice; English Nature: Peterborough, UK, 2006; pp. 1-145.

3. Reynard, E.; Brilha, J. (Eds.) Geoheritage: Assessment, Protection, and Management; Elsevier: Amsterdam, The Netherlands, 2018; pp. 1-482.

4. Costanza, R.; dArge, R.; de Groot, R.; Farber, S.; Grasso, M.; Hannon, B.; Limburg, K.; Naeem, S.; Oneill, R.V.; Paruelo, J.; et al. The value of the world's ecosystem services and natural capital. Nature 1997, 387, 253-260. [CrossRef]

5. Costanza, R.; de Groot, R.; Braat, R.; Kubiszewski, I.; Fioramonti, L.; Sutton, P.; Farber, S.; Grasso, M. Twenty years of ecosystem services: How far have we come and how far do we still need to go? Ecosyst. Serv. 2017, 28, 1-16. [CrossRef]

6. Sheng, H.-X.; Xu, H.; Zhang, L.; Chen, W. Ecosystem intrinsic value and its application in decision-making for sustainable development. J. Nat. Conserv. 2019, 49, 27-36. [CrossRef]

7. Brilha, J.; Gray, M.; Pereira, D.I.; Pereira, P. Geodiversity: An integrative review as a contribution to the sustainable development of the whole of nature. Environ. Sci. Policy 2018, 86, 19-28. [CrossRef]

8. Ruban, D.A.; Tiess, G.; Sallam, E.S.; Ponedelnik, A.A.; Yashalova, N.N. Combined mineral and geoheritage resources related to kaolin, phosphate, and cement production in Egypt: Conceptualization, assessment, and policy implications. Sustain. Environ. Res. 2018, 28, 454-461. [CrossRef]

9. Bruschi, V.M.; Cendrero, A. Geosite evaluation; can we measure intangible values? IL Quat. Ital. J. Quat. Sci. 2005, 18, 293-306.

10. Brilha, J. Inventory and Quantitative Assessment of Geosites and Geodiversity Sites: A Review. Geoheritage 2016, 8, 119-134. [CrossRef]

11. Coratza, P.; Giusti, C. Methodological proposal for the assessment of the scientific quality of geomorphosites. IL Quat. Ital. J. Quat. Sci. 2005, 18, 307-314.

12. Panizza, M. Geomorphosites: Concepts, methods and examples of geomorphological survey. Chin. Sci. Bull. 2001, 46, 4-6. [CrossRef]

13. Pereira, P.; Pereira, D.; Caetano Alves, M. Geomorphosite assessment in Montesinho Natural Park (Portugalia). Geogr. Helv. 2007, 62, 159-169. [CrossRef]

14. Reynard, E. Geomorphosites et paysages. Geomorphol. Relief Process. Environ. 2005, 3, 181-188. [CrossRef]

15. Serrano, E.; Gonzalez-Trueba, J.J. Assessment of geomorphosites in natural protected areas: The Pico de Europa National Park (Spain). Geomorphol. Relief Process. Environ. 2005, 3, 197-208. [CrossRef]

16. Zouros, N. Geomorphosite assessment and management in protected areas of Greece. Case study of Lesvos Island-Coastal Geomorphistes. Geogr. Helv. 2007, 62, 169-180. [CrossRef]

17. Migoń, P.; Pijet-Migoń, E. Viewpoint geosites-Values, conservation and management issues. Proc. Geol. Assoc. 2017, 128, 511-522. [CrossRef]

18. Habibi, T.; Ponedelnik, A.A.; Yashalova, N.N.; Ruban, D.A. Urban geoheritage complexity: Evidence of a unique natural resource from Shiraz city in Iran. Resour. Policy 2018, 59, 85-94. [CrossRef] 
19. Zangmo, G.T.; Kagou, A.D.; Nkouathio, D.G.; Gountié, M.D.; Kamgang, P. The Volcanic Geoheritage of the Mount Bamenda Calderas (Cameroon Line): Assessment for Geotouristic and Geoeducational Purposes. Geoheritage 2017, 9, 255-278. [CrossRef]

20. Kirillova, K.; Fu, X.; Lehto, X.; Cai, L. What makes a destination beautiful? Dimensions of tourist aesthetic judgment. Tour. Manag. 2014, 42, 282-293. [CrossRef]

21. Ruban, D.A. Quantification of geodiversity and its loss. Proc. Geol. Assoc. 2010, 121, 326-333. [CrossRef]

22. Gulcin, D.; Yilmaz, K.T. The assessment of landscape fragmentation in an agricultural environment: Degradation or contribution to ecosystem services? Fresenius Environ. Bull. 2017, 25, 7941-7950.

23. Adamia, S.; Alania, V.; Chabukiani, A.; Kutelia, Z.; Sadradze, N. Great Caucasus (Cavcasioni): A Long-lived North-Tethyan Back-Arc Basin. Turk. J. Earth Sci. 2011, 20, 611-628.

24. Saintot, A.; Brunet, M.-F.; Yakovlev, F.; Sébrier, M.; Stephenson, R.; Ershov, A.; Chalot-Prat, F.; McCann, T. The Mesozoic-Cenozoic tectonic evolution of the Greater Caucasus. Geol. Soc. Lond. Mem. 2006, 32, $277-289$. [CrossRef]

25. Rolland, Y. Caucasus collisional history: Review of data from East Anatolia to West Iran. Gondwana Res. 2017, 49, 130-136. [CrossRef]

26. Gnezdilova, V.V.; Ruban, D.A.; Bruno, D.E.; Perrotta, P.; Crowley, B.E.; Oheim, K.B.; Zayats, P.P. Geoheritage sites with palaeogeographical value: Some geotourism perspectives with examples from Mountainous Adygeja (Russia). Geološki anali Balkanskoga Poluostrva 2015, 76, 93-104. [CrossRef]

27. Veress, M.; Telbisz, T.; Tóth, G.; Lóczy, D.; Ruban, D.A.; Gutak, J.M. Glaciokarsts; Springer: Cham, Switzerland, 2019; pp. 1-516.

(C) 2019 by the authors. Licensee MDPI, Basel, Switzerland. This article is an open access article distributed under the terms and conditions of the Creative Commons Attribution (CC BY) license (http://creativecommons.org/licenses/by/4.0/). 